\title{
NBSIR 74-444
}

\section{A Review of Natural Stone Preservation}

Gerald A. Sleater

Center for Building Technology

Institute for Applied Technology

National Bureau of Standards

Washington, D. C. 20234

December 1973

Preliminary Report

Prepared for

National Park Service

Department of the Interior

Washington, D. C. 20240 


\section{A REVIEW OF NATURAL STONE PRESERVATION}

Gerald A. Sleater

Center for Building Technology Institute for Applied Technology National Bureau of Standards

Washington, D. C. 20234

December 1973

Preliminary Report

Prepared for

National Park Service

Department of the Interior

Washington, D. C. 20240

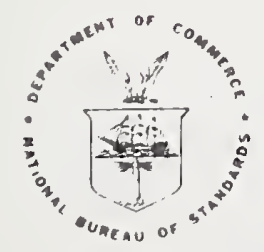

U. S. DEPARTMENT OF COMMERCE, Frederick B. Dent, Secretary 



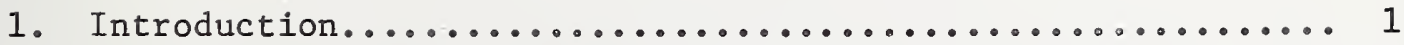

1.1 Sponsorship, Scope of Program................... 1

1.2 The Need for Stone Preservation................. 1

2. The Major Causes of Stone Decay..................... 2

2.1 Types of Stone Subject to Stone Decay.............. 2

2.2 Stone Decay Through Physical Faults in Stone or Improper Use of Stone...................... 2

2.3 The Influence of Water on Stone Decay............ 4

2.4 Stone Decay from Natural Weathering.............. 5

2.5 Decay of Stone from Sulfur Dioxide.............. 6

2.6 Decay of Stone from Carbon Dioxide............... 6

2.7 Stone Decay from Salts..................... 7

2.8 Stone Decay from Living Organisms.............. 7

3. Stone Preservatives and Preservation................. 8

3.1 Introduction.......................... 8

3.2 Maintenance of Stone Structures................ 8

3.3 Cleaning of Stone............................ 9

3.4 Paint, Waxes, and Oils Used as Surface Coatings in Stone Preservation........................ 10

3.5 Inorganic Materials Used as Stone Preservatives........ 10 3.5.1 Silica-Depositing Stone Preservatives......... 11

3.5.2 Calcium Hydroxide (Limewater) Used as a Stone Preservative........................ 12

3.5.3 Alkaline Earth Stone Preservatives........... 12

3.6 Silicones and Siliconates Used as Stone Preservatives.. 13

3.7 Synthetic Organic Polymers Used as Stone Preservatives............................ 14

4. Suggestions for the Evaluation of Stone Preservatives....... 16

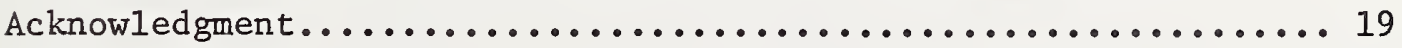
APPENDIX A - Test Procedures for the Physical Properties of

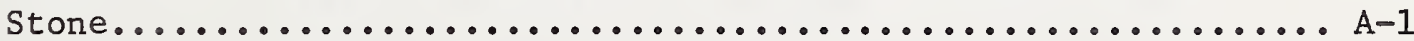


TABLE OF CONTENTS (continued)

Page

APPENDIX B - Field Trials of Stone Preservatives by the Building Research Establishment, Great Britain.............. B-1 APPENDIX C - A Scientific Approach to the Choice of a Stone Preservative................................ C-1 APPENDIX D - Methods for Cleaning Natural Building Stone....... D-1 APPENDIX E - Suggestions for a Laboratory Test Program to Evaluate Stone Preservatives.......................... E-1 APPENDIX F - Glossary of Technical Terms.................F-1 APPENDIX G - Source Materials: Bibliography................ G-1

G.1 Source Materials on Stone Preservation..............G-1

G.2 Bibliography.............................G-2 


\section{ABSTRACT}

With increased interest in stone preservation, it is desirable to know what causes stone to decay, and what materials can be used to preserve stone. This review covers the following topics: causes of stone decay, including faults in the stone, salts, natural weathering factors, air pollution, living organisms, and most importantly, water action; various materials that have been used to preserve stone, including paints, waxes, oils, inorganic chemical surface treatments and impregnants, silicones, siliconates, and synthetic organic polymers; methods of evaluating stone preservatives. Field and laboratory procedures for testing stone preservatives, the cleaning of stone, a glossary, and a bibljography are given in appendices. 



\section{Introduction}

\subsection{Sponsorship, Scope of Program}

The Center for Building Technology is engaged in research sponsored by the National Park Service, Department of the Interior, on the methods and materials used in the preservation of building stone. This review of stone preservation completes the first phase of the program. Following phases will include laboratory and natural weathering tests of stone specimens treated with various materials that can be used for stone preservation. At the conclusion of the program, it is intended to publish another report in which the methodology and findings of the research phases will be described.

This report covers only stone. Stone is the building material of most general interest in conservation and preservation. Its qualities of strength, workability, availability, and aesthetic appeal, have made it the material of choice for most great structures of present historic interest. This report is intended to furnish useful information to those people interested in obtaining a general background in stone preservation. No original research will be discussed.

There are three main sections in the report. In the first section, the main causes of stone deterioration, or stone decay, are discussed. The second section describes the techniques and materials that have been developed for stone preservation. The third section of the report lists suggestions for evaluating stone preservatives. Several topics of interest to those involved in stone preservation are covered in a series of appendices.

\subsection{The Need for Stone Preservation}

In recent years there has been an increasing realization that buildings and monuments of the past are the heritage of the present and the future, and that to preserve this heritage there must be an immediate and worldwide response.

In the United States the efforts to preserve and conserve historic buildings and monuments have been on both the local and the national level. The Federal Government has initiated a National Register Program by which the Secretary of the Interior is empowered to "expand and maintain" a National Register of "districts, sites, buildings, structures, and objects of historical, archaeological, architectural, or cultural significance," and to assist local government in the acquisition and the preservation of such properties [1]*.

In 1971 President Nixon, in stressing the need to preserve the architectural and historic heritage of the United States, urged the expansion

*Numbers in brackets refer to the references found in Appendix G. 
of this national concept to one of an international "World Heritage Trust" [2]. Governments in Europe and in the Western Hemisphere have cooperated in multinational conservation and preservation projects [3]. The United Nations Educational, Scientific, and Cultural Organization (UNESCO) has made two important contributions on the international leve1: The International Centre for the Study of the Preservation and Restoration of Cultural Property, established in 1958 in Rome, and the International Council of Monuments and Sites (ICOMOS) established in 1965.

Such organized activities are, however, only part of conservation and preservation. Efforts to combat material deterioration must be based upon scientific investigation and technological capability. Whether deterioration is slight or extensive, continuous or periodic, there is need both to understand what is happening and to have the techniques and materials that will effectively prevent or retard its progress.

\section{The Major Causes of Stone Decay}

\subsection{Types of Stone Subject to Stone Decay}

In this report the term stone decay covers any irreversible change in the soundness of natural building stone. This change may be due to a normal chemical transformation of the stone's mineral composition upon exposure to natural weathering, or it may be due to one of the specific causes of stone decay described in the following sections.

The stones most likely to be affected by stone decay are stones quarried from the sedimentary groups (limestones*, sandstones*) and metamorphic group (marbles*) of natural rock. Building stone cut from igneous rocks (granites*, for example) do not normally evidence deterioration, as, in general, they have a more inert mineral composition, a lower water absorptivity, and a greater hardness than stones from the other two groups of rock mentioned.

\subsection{Stone Decay Through Physical Faults in the Stone or Through Improper Use of the Stone}

The onset of immediate and widespread stone decay in a structure is evidence that the stone is not durable in its environment. A noteworthy example of this occurred in the choice of stone used in the construction of the British Houses of Parliament in the mid-nineteenth century (18401847) [4]. The Anston dolomitic limestone chosen was initially a structural1y stable building material; however, the stone was permeated with minute fissures (vents*) through which the polluted London atmosphere penetrated. The resultant chemical attack on the stone led to rapid decay and necessitated replacing the Anston stone with the more stable Clipsham limestone [5]. In this instance the stone decay was abetted

*Defined in Appendix F. 
by the highly decorative surface carvings indigenous to the neo-Gothic architecture of the building, as more "vents" were exposed by it than would have been the case if only plane, uncarved stonework had been used. In fact, plane-surfaced London buildings of the same dolomitic limestone, built at the same-time as the Houses of Parliament, have remained structurally sound [6].

A similar problem occurs when several different types of stone have been used in building one structure. An example of this is the great Gothic cathedral of Cologne, Germany, where air pollution is causing serious stone decay. Sixteen different types of stone have been identified as having been used during the 500 years of its building.

The avrying properties of such a variety of stones complicates efforts to retard stone decay, for a treatment effective for one type of stone may not be effective for another type [7].

Physical faults or occlusions in quarried stone may cause stone decay. Physical faults are exemplified by the vents of the Anston stone used in the Houses of Parliament. Such faults most likely occur through earth movements acting upon the rock from which the stone was quarried [8]. The effect of soluble salts occluded in stone is discussed in Section 2.7. Mineral occlusions, such as pyrites, often oxidize upon exposure to the air, staining the stone.

In sedimentary stones, there may be a nonuniformity of hardness among the layers of the stone. As natural weathering proceeds, this may result in a furrowed surface as softer layers preferentially weather away or harder layers or veins become more prominent. The layered structure of sedimentary stones makes it necessary to lay them with the natural bedding planes horizontal. If laid vertically, the weight pressing down across the layer boundaries may split the layers and cause spalling.

Materials in contact with building stones must be compatible with the stones; such materials include mortars, metal clamps, or even different types of stone. Mortars that are attacked by sulfur dioxide can yield calcium sulfate (gypsum) which, if leached into calcareous stone, can head to efflorescence, even spalling (see Section 2.7). The siliceous binders of some types of sandstone are reported to be destroyed by calcium sulfate leached from mortars or limestones that have been attacked by sulfur acids [9].

Metals in contact with stone, particularly ferrous metals, can damage the stone. Iron dowels, clamps, rods, pins, etc. can be expected to rust eventually. The rust that is formed has a greater volume than the iron, and the pressures that build up may crack the stone [10]. (Stainless steels or special non-rusting alloys can be used in contact with stone). Staining of stone by corroding metals can lead to decay of the stone. In a study of marbles stained by runoff from bronze fixtures attached to the stone, it was observed that in some instances where the stains were brown (from cupric oxide), the marble was decaying; no instances of marble decay were observed where the stains were green 
(from basic cupric carbonate); no definite conclusions were given as to the cause of the decay, nor why one color stain sometimes led to decay and the other did not [11].

\subsection{The Influence of Water on Stone Decay}

The importance of water in stone decay cannot be underestimated. Stone decay through salt action or chemical action is always dependent upon the presence of water. The dissolution and water transport of soluble salts within stone may cause efflorescence and salt-induced spalling. Water is the solvent for gaseous pollutants that chemically attack the stone. Freezing of water-saturated stone may develop sufficient pressure to cause spalling or cracking of the stone. Frost damage is possible in all climates where freezing temperatures can occur, however rarely. In 1963 severe frost conditions caused extensive damage in the Roman Forum [12].

The danger of water penetrating into a stone structure is increased by errors in building design or by lack of proper maintenance. Stone can become water-saturated when gutters, drains, or downspouting fail to carry rain or melting snow down and away from a structure; blockage of any of these units will cause the same problem. Copings or parapets, especially of porous stone, tend to absorb water, which will then seep into the stonework below; proper flashing or waterproofing members must be used to prevent this seepage.

Open building joints are particularly serious points for water entry, especially at building units -- balconies, stringcourses, moldings, sills, cornices - that tend to catch rainwater or concentrate its runoff. Groundwater, with dissolved salts, will be drawn up into building walls, retaining walls, or monument bases by capillary action if dampproof courses have been omitted in their construction. Water permeation may also occur when regions of high humidity within a structure are not properly isolated from the other walls.

\subsection{Stone Decay from Natural Weathering}

Some aspects of weathering upon stone are acceptable, even desirable. With some stone, the color changes and mellowing of new stonework incident to natural weathering are aesthetically pleasing effects. Such changes in a stone surface are not necessarily indicative of stone decay.

It is, however, the degrading effect of natural weathering upon stone which is of most interest. The weathering agents that commonly foster stone decay are rain (or snow), temperature, wind, and atmospheric gases (including air pollution); these may act alone, combine with each other, or influence other decay-causing agents.

The effect of rain on stone is the effect of water, which was discussed in Section 2.3. 
Ambient temperatures may affect stone decay in several ways: variations of temperature affect the transport of salts in stone (see Section 2.7); below freezing temperatures are necessary for frost damage to stone (see Section 2.3); diurnal temperature changes may set up thermal stresses in the mineral components of a stone.

Studies of the effects on granites of normal ambient temperatures $\left(-20^{\circ}\right.$ to $\left.+60^{\circ} \mathrm{C}\right)$ indicated that in the presence of moisture the expansion and contraction of the stone would have a long term effect on the durability of the stone [13].

The possibility of physical displacement of stonework through thermal expansion of the stone should be considered -- especially for large surface areas of stone veneer -- and suitable expansion joints employed where necessary.

Wind can blow down weakened or insecure building elements. It may also act as a carrier for solids, chemicals, or salts. There are instances where wind alone has damaged stonework.

Windblown solids can act as abrasives. Abrasion damage is expected only through long term repetition. However, in one reported incident, windblown pebbles seriously damaged part of an Abu Simbel statue during its transfer [14]. Wind can blow away mortar from exposed building joints [15]; in one instance, the singular design of a chamber developed a vortex condition whereby the wind scoured the stone from the chamber walls [16].

Prevailing winds may preferentially direct air pollutants or carry them long distances from their sources [17]. Sea salts are carried inland by breezes off the ocean (see Section 2.7). Deposits of airborne particulate matter -- soot, dirt, fly ash -- discolor stone. If permitted to build up, these deposits may form a water-impermeable skin that clogs the pores of the stone, or, depending upon their composition, chemically attack the stone. Conversely, winds may keep certain areas of a structure dry, while other areas remain water-saturated.

The acidic gaseous components of air pollution are principally the combustion products of fossil fuels [18]. Only carbon dioxide and sulfur dioxide will be discussed. Other pollutant gases, such as the oxides of nitrogen, may be significant factors in some stone decay; however, there is insufficient information about them to make a general statement of their role in stone decay.

\subsection{Decay of Stone from Sulfur Dioxide}

It is generally believed that sulfur dioxide is the main corrosive agent in urban stone decay [20]. When sulfur dioxide is dissolved in water, sulfurous acid is formed; this acid can attack stone and other building materials [21]. 
Both sulfurous acid, and the sulfite salts that result from its chemical reactions, can be oxidized by oxygen to sulfuric acid and sulfate salts, respectively. Sulfuric acid is a stronger, more destructive acid than sulfurous acid. The sulfate salts, however, that are formed either by the chemical action of sulfuric acid, or by the oxidation of sulfite salts, are more soluble than the corresponding sulfite salts. In stone decay, these sulfate salts are mainly calcium sulfate (usually in the form of gypsum, calcium sulfate dihydrate) in calcareous stones, or magnesium sulfate (in the hydrated form of epsom salt, magnesium sulfate septahydrate) in dolomitic stones. If these salts are formed on the surface of a stone structure, efflorescence of the stone can occur, or if they are concentrated through water transport, spalling may result.

\subsection{Decay of Stone from Carbon Dioxide}

Most carbon dioxide in the atmosphere comes from natural photosynthesis. Urban sources of carbon dioxide -- factory or automobile emissions -may lead to concentrations above the accepted atmospheric norm of $0.034 \%$ [22] .

The low solubility of carbon dioxide in water gives a weak acid, carbonic acid, that is in general not corrosive to building materials [23]. However, carbonic acid does possess unique solvent properties in respect to carbonate-containing minerals. The major chemical constituents of the marbles and limestones, the minerals calcite (calcium carbonate) and dolomite (calcium magnesium carbonate), and the calcareous binders of some sandstones are therefore susceptible to chemical attack by carbonic acid.

The ubiquitousness of carbon dioxide and water posits a potentially serious destructive process towards carbonate building stones. In reality this is not the case. Although the calcareous components of sandstones can be dissolved [24], the solvent action on marbles and limestones is not appreciable when compared to their decay from other agents. This may be ascribed to the slowness of the leaching process, and the generally greater porosity and water absorption of sandstones relative to marbles and limestones.

\subsection{Stone Decay from Salts}

In general, the presence of salts in stone is due to: natural sources (salts dissolved in groundwater that has permeated the stone before quarrying), pollution (salts that were present in rainwater, ocean spray, or particulate matter, or that resulted from chemical attack on the stone), or miscellaneous factors (residues from stone cleaners, salt decay products from mortars or other materials in the structure [25]).

Water is the transport medium for salts. When after transport dissolved salts recrystallize, there can, in general, be two effects on the stone: either the salts deposit on the surface of the stone, causing efflorescence, 
or they collect beneath the surface of the stone in quantities that can cause spalling of the stone.

In some instances, calcium sulfate deposits form glassy, adherent skins on the stone; these skins cannot be removed by normal cleaning operations [26].

\subsection{Stone Decay from Living Organisms*}

Trees or similarly large vegetation growing near a stone structure can damage the stone by the branches buffeting the walls or by the root systems penetrating the structure's foundation [27].

The picturesqueness of ivy-covered stone walls obscures the harmful effects that such growths have on the stone to which they cling. The matted growth cuts off air circulation and consequently retains moisture in the stone. The roots of the attached vines grow over and into the masonry, eventually crumbling both stone and mortar [28]. (A positive aspect of ivy is that it will possibly protect the wall from the full force of a driving rain.)

Less visible are the effects of living organisms. The growth process and secretions of some lichens are said to dislodge stone particles [29]. Bacteria present a more specialized case: certain species are known to secrete specific stone-attacking acids [30]. French investigators have ascribed the similarity of certain forms of stone decay in differing environments to similarly favorable conditions for the growth of bacteria [31].

Most people examining stone decay do not have the specialized training needed to investigate microorganisms. Perhaps this lack of knowledge is one reason that has limited research into the bacterial attack of stone.

\section{Stone Preservatives and Preservation}

\subsection{Introduction}

Stone decay has been discussed at length in order to stress the diversity of its causes. Recognizing the cause of stone decay is the first step in stone preservation; eliminating its cause, or protecting against it, is the next step. Only then should stone preservation treatments be undertaken on stone that still possesses the strength to be useful.

*A literature study of the microbiological deterioration of porous inorganic building materials, compiled by E. H. Hueck-van der Plas, has been published in the International Biodeterioration Bulletin, 4, 11-28 (1968). 
Deteriorated stone should be replaced when decay has progressed to the point where the stone is no longer structurally stable. Although the specialized techniques for restoring or replacing decayed stone are outside the topic of stone preservation, consideration should be given to combining stone preservative treatments with stone restoration work. [Examples of stone restoration can be found in reference 27].

When stone decay arises from a cause that can be prevented, or at least controlled, (for example, water penetration into the stone structure), its elimination can be effected. When the cause is a phenomenon over which there is no immediate control (for example, air pollution), its effects can only be protected against or mitigated. Stone preservatives have a dual purpose: first, to protect sound stone from the effects of stone decay; second, to impregnate and harden decayed stone.

The decay of stone in the British Houses of Parliament (Section 2.2) had the unforeseen dividend of stimulating the development of stone preservatives. Stone deterioration in such an important building was an incentive for applied chemistry, which, by the mid-nineteenth century, had progressed to the point where the solution of the problem seemed feasible. Some of the methods that were advanced for stone preservation between 1855 and 1872 included treatments with waxes, oils, fluorosilicates, limewater, and barium hydroxide [32]; all of these are still mentioned as stone preservatives.

Each of the above methods will be described in the following sections together with stone preservatives that incorporate materials and techniques developed only recently. As stone preservatives are applied to stone only after the stone has been cleaned and repaired, cleaning and maintenance programs will be discussed before the stone preservatives.

\subsection{Maintenance of Stone Structures}

The care of any stone structure should include a maintenance program designed to prevent the causes or to detect the inception of stone decay. Such a program should consist of routine inspections with a maintenance checklist that includes the following points.

Rubbish and dirt (including bird droppings) that accumulate around the structure or on the stone may mask or initiate stone deterioration; they should be removed. Organic growths or salt deposits adhering to the stone should be removed and their causes investigated.

Tree branches and root systems that are in contact with the structure should be cut back. Drainage systems should be checked and re-opened when necessary. Open joints and cracks in the stone, especially where water collects, should be closed; the cause of cracking should be determined and rectified. The mortar or caulking used in repointing and 
in filling cracks should be chemically inert to the stone and should not be too hard for the stone. (An exposition of the faults to be avoided in repointing, together with formulas for appropriate mortars, can be found in reference [33].) Any repair work should not detract from the appearance of the existing stonework.

\subsection{Cleaning of Stone}

There are several incentives for cleaning stone structures. For new structures, a program of periodic cleaning will help to retain a good appearance and will complement the maintenance program by preventing the build up of surface deposits. Older structures will benefit from cleaning, for the practical reason that surface deposits which may be deleterious to the stone will be removed, and the color and texture of the original stonework once more revealed.

The cleaning of stone is a prerequisite for stone preservation. A dirty stone surface will prevent or retard penetration of the treatment into the stone; any cementative action of the preservative on the stone will trap surface deposits, not remove nor neutralize them; consolidation of a dirty or decayed surface will invite spalling or flaking of the stone.

The dirtied appearance that some monuments have developed over the years may have become accepted as part of the monument itself, and the effect on public opinion that cleaning might have should be considered before cleaning. The aesthetic and practical need for cleaning, together with the experience with domestic or foreign structures that have been improved by cleaning, can be cited as proof of the value of cleaning.

Rain is a natural cleansing agent. Its effect on open surfaces -overlooking the deleterious aspects of possible water penetration--can prevent certain instances of stone decay. Several theories have been advanced as to why stone decay is often more serious where the stone is protected from rain; the gradual concentration, hence greater shattering effect of calcium sulfate is one [34]. Another theory was proposed for the decay observed at the Athenian Parthenon [35]. Dust (clay, silica, soot) that collected on stone protected from rain acted as a contact catalyst, converting atmospheric pollutants to sulfuric and nitric acids that attacked the stone. To back up this claim, it was noted that the stone was discolored only in these protected areas; the discolorization was ascribed to oxidation of the traces of colorless ferrous iron in the marble to red-brown ferric iron by the oxidizing acids.

A short review of present commercial processes that can be used in cleaning natural stone structures is given in Appendix D. 
3.4 Paints, Waxes and Oils Used as Surface Coatings in Stone Preservation

The use of paint as a protective coating for metal and wooden building materials suggests its use for the protection of building stone. If properly applied and maintained, a paint layer will act as a protective coating for the stone [36]. The drawback of paints is that they conceal the fabric of the stone and alter the color of the structure.

Oils, such as linseed oil, can be applied by brush or spray and will dry to a tough coating, sealing the pores of the stone. Although there is no pigmentation added to the oils, experience has shown that they will, with time, darken the stone [37].

Solid waxes must be dissolved in a solvent or be applied molten to stone. By either application, the stone should be heated to increase the depth of wax penetration into the stone. However, heating exterior stone presents a problem: the stone must be heated sufficiently to assist penetration, but not to such a temperature that spalling will occur. Paradoxically, high summer temperatures may melt some waxes, causing them to flow from the stone. (The difficulties involved in outside wax impregnation are noted in reference [38].) Small objects may be impregnated, after drying or purging the stone of water, by immersion in a bath of molten wax; deep penetration is achieved, and a controlled temperature assures no damage to the stone from overheating.

Although paints, oils, and waxes do not chemically react with stone, they do seal the pores of the stone and form a thin, water-impermeable surface layer. Consequently, if salts are already present in the stone, there is a danger of spalling. The changes in color of the stone after surface coatings are applied also mitigates against their use. With the advent of newer stone preservatives, the above treatments are limited to specific, interior usage [39].

\subsection{Inorganic Materials Used as Stone Preservatives}

The use of inorganic materials as stone preservatives is an effort to incorporate in the body of stone a decay-resistant phase that will bind together the grains of decaying stone. The most obvious materials to use in this regard are those similar in composition to mineral components of natural building stone, such as silica and calcium carbonate.

\subsubsection{Silica*-Depositing Stone Preservatives}

Silica, the main constituent of sand, is an inert, stable chemical compound. The quartz grains of sandstones are one crystalline form of

* Silica $\left(\mathrm{SiO}_{2}\right)$ is an inorganic compound of the chemical element silicon (Si). Silicon should not be confused with the silicon-containing chemical compounds known as silicones (note the ' $e$ ' on the end of silicone). 
silica. Decay of sandstone results from dissolution of the binder holding the grains of quartz together, the quartz grains being unaffected. Silica precipitated within a stone matrix would both give the grains of stone a protective coating and bind them together. The following methods have been proposed to accomplish such an in situ silica precipitation.

Sodium and Potassium Silicates -- Water solutions of these compounds precipitate colloidal silica when exposed to air. However, alkali is also released by the hydrolysis with a consequent problem of efflorescence [40]. Limited penetration of the preservative into the stone must also be considered. However, recent usage of preservatives of this type is said to give satisfactory performance [41].

Silicon Esters - The silicon esters are organic compounds of silicon, soluble in organic solvents, but which breakdown into colloidal silica and alcohol in the presence of water. The viscosities of the organic solvents are lower than water and allow the silicon esters to penetrate deeper into the stone than sodium or potassium silicates. The colloidal silica forms an adherent coating on the grains of the stone, and no inorganic salts are formed by the reaction with water.

Silicofluorides -- The use of hydrofluorosilic acid and soluble silicofluoride salts (often commercially referred to as "Fluates") as stone preservatives depends upon their chemical reaction with the stone. The action of the hydrofluorosilic acid is too vigorous for its use upon stones containing calcium carbonate; its reaction with non-calcareous sandstone results in surface hardening of the stone [42]. Conversely, the silicofluoride salts react with calcium carbonate to form silica and insoluble fluorides; again, there is only a surface hardening of the stone [43].

As the acids and the salts begin to react with the stone matrix as soon as they are applied, the consolidation and hardening of the stone will be a surface effect that may lead to future spalling. Possible change of color in the building stone and formation of soluble salts from the chemical reactions should be considered, as should the drawbacks of these treatments being a chemical attack on the stone matrix.

\subsubsection{Calcium Hydroxide as a Stone Preservative}

Limewater is a saturated calcium hydroxide solution. The low water solubility of calcium hydroxide (approximately 1 gram per liter at room temperature [44]) yields a strongly basic, though not caustic, solution. The usefulness of limewater treatments lies in the precipitation of calcium carbonate by the reaction of limewater with carbon dioxide in the air. Therefore, by treating building stones with limewater, calcium carbonate is slowly precipitated in situ after the limewater has been absorbed by the stone. For calcareous stones, a chemically identical compound will be formed which may bind the stone grains together. The treatment may also be used for other than calcareous building stones. 
The low water solubility of calcium hydroxide makes repeated applications of limewater necessary to bring about any cementing effect on the stone. As the precipitation of calcium carbonate is dependent upon absorption of carbon dioxide from the air, it begins at the surface of the stone, then proceeds into the stone; the precipitation of calcium carbonate in the pores of the stone blocks absorption of more limewater, thus limiting the penetration of the treatment into the stone.

\subsubsection{Alkaline Earth Stone Preservatives}

Calcium carbonate precipitated within stone by limewater is as liable to chemical attack as any calcareous stone or binder. When the stone is attacked by sulfur acids, the calcium sulfite or calcium sulfate that is formed can be carried by water throughout the stone. In order to avoid this problem, strontium hydroxide and barium hydroxide solutions have been used in place of the calcium hydroxide solutions in treating stone. These alkaline earth hydroxides will also react with carbon dioxide, resulting in precipitation of the respective carbonates, but unlike the respective calcium salts, the sulfites and sulfates of these elements, if formed, are insoluble in water.

Attempts to preserve stone with strontium or barium hydroxide treatments were first reported in 1862 [45]. As with a limewater treatment, the precipitation of the insoluble carbonate is dependent upon the carbon dioxide in the air; but the deeper the hydroxide solution has penetrated into the stone, the farther the solution is likely to be from the carbon dioxide precipitant.

Recently developed inorganic stone preservation treatments attempt to overcome poor penetration into the stone through the use of the technique known as precipitation from homogeneous solution [46]. Through this technique both the substance to be precipitated and the precipitating agent are present in the same solution; the condition of the solution prevents initiation of precipitation. By subsequently changing the condition of the solution (by heating for example), a chemical reaction begins that slowly releases the precipitating agent. Thus the precipitate is formed in situ wherever the solution has penetrated, as it is not dependent upon the precipitating agent diffusing into the stone from the surface.

In one treatment [47], barium carbonate is precipitated from a barium hydroxide solution by hydrolysis of urea in the solution, through which carbon dioxide and ammonia are slowly released. As the solution reaches the proper alkalinity from the ammonia, the carbon dioxide simultaneously evolved precipitates barium carbonate. The slow formation of barium carbonate is claimed to give a crystalline solid solution with the calcite crystals of calcareous stone. If the stone is attacked by sulfur acids, the insoluble barium salts formed treated cannot be transported by water through the stone. 
Barium sulfate or strontium sulfate can be deposited within stone by an analogous precipitation technique: solutions of strontium and barium monoesters of sulfuric acid slowly hydrolyse, releasing barium, strontium, and sulfate ions, when a base is added [48].

The liquid solutions are applied to the stone surface by brushing or spraying; smaller stone objects may be completely immersed. The strong bases, strontium or barium hydroxide, are needed for both treatments: in the first, as the source of strontium or barium ions; in the second, to initiate hydrolysis and neutralize any acid formed by hydrolysis. By proper mixing before treatment, or by thorough washing afterward, excess base should be avoided or removed.

The newness of homogeneous solution precipitation treatments preclude long term examples of the effectiveness of the treatments. Possibly the greatest drawback to these treatments was noted by the man who first reported the use of strontium and barium hydroxide as stone preservatives: the chemical compounds formed within the stone have a different molecular volume than the components of the stone matrix [49]. However, as these treatments are intended for use on stone that is in need of consolidation, it is anticipated that the body of the stone should have opened up sufficiently to accommodate the precipitated compounds that are intended to bind the stone particles together.

\subsection{Silicones* and Siliconates Used as Stone Preservatives}

The commercial development of silicone-based water repellents following World War II offered a new type of material for stone preservation. By preventing the penetration of liquid into building stone, these treatments preclude the introduction into the stone of one of the major agents in stone decay. The silicone or siliconate treatments are applied to the stone in dilute solutions of one to five percent after dilution with organic solvents or water, respectively. Spray application is recommended.

The silicone treatments coat the walls of the stone capillaries with a water repellent film that will still allow water vapor to pass, hence the stone may "breathe". The repellency lasts several years, and treatments may be repeated when wetting of the stone by rain indicates diminished water repellency. Silicone treatments are normally recommended for use on sloping or vertical surfaces, as liquid water will pass through the treated zone if the surface is flooded with a large volume of water.

Water soluble silicones (an aqueous solution of an alkali metal salt of a silicone) are commonly referred to as siliconates. Their solutions are alkaline and a hard film, difficult to remove, is formed as the siliconate reacts with the water and carbon dioxide in the air. 
Most water-insoluble silicones coat the pores of the stone as the organic solvent in which they are dissolved evaporates. Their use has the advantage that no inorganic salts are introduced into the stone.

Although the water repellent treatments leave a colorless coating on the stone, the alkaline medium of one and the organic solvent of the other may react with occlusions in the stone and lead to patches of discolorization; the stone should therefore be tested for this before their widespread application. As with any treatment applied to the surface of stone, the depth of penetration of the treatment must be considered. Because water repellent treatments do not usually penetrate into the stone, water diffusing to the surface will deposit salts at the meniscus behind the thin water repellent zone.

Another point to consider in using water repellent treatments is the possible increase of the water flowing off the surface, and the need for adequate drainage systems. Water spilloff from a water repellent surface is another incentive to closing all joints.

Combining silicone treatments with other types of stone preservatives has been suggested, the silicone furnishing the water repellency the other treatments may lack [50]. In addition, silicones, in repelling water, also prevent entry of salts or corrosive materials dissolved in the water. This property of repellency should prove useful near the ocean where the moisture carried inland contains dissolved sea salts. (See Appendix C).

\subsection{Synthetic Organic Polymers* Used as Stone Preservatives}

As with the silicone water repellents, the use of synthetic polymeric materials as stone preservatives is a recent development. Unlike the silicones, which are intended as surface treatments, polymers can penetrate into the stone and form a hard, durable phase that will consolidate the stone.

Penetration of polymer solutions into the stone is favored by the use of organic solvents to dilute the resin*. The deeper the penetration of a preservative, the less the danger of a shallow treated zone behind which salts can build up. The use of organic solvents avoids the introduction of soluble salts into the stone. Although usually colorless and inert to the stone, polymers may impart a luster to the stone surface [51].

With some polymers, there is the possibility that the impregnation process may be at least partly reversed, the polymer being removed from the stone by a solvent treatment. It is, however, doubtful that any polymer treatment should be undertaken on the premise that it can be removed should it prove necessary [52].

*Defined in Appendix $\mathrm{F}$. 
In the simplest treatment procedure, the polymer resin dissolved in an organic solvent is applied to the stone; when the solvent evaporates, the polymer remains in the stone. This type of treatment has the drawback that as the solvent evaporates from the surface, it tends to pull the dissolved resin-back to the surface [53]. Then, too, even diluted to the lowest concentration that will give effective protection, solutions of resin have a viscosity that lessens deep penetration into the stone. Multiple applications will be necessary [54].

In a more elegant method of application, monomers* in a solvent system are polymerized after the solution has penetrated into the stone. Polymerization is controlled by initiators/activators which are dissolved in the solvent [55, 56]. This in situ polymerization is regulated by the activators (such as aromatic amines) that delay polymerization before the solution has penetrated into the stone, and initiators (such as organic peroxides) that begin the polymerization after penetration.

Single applications of such solutions should suffice for a preservation treatment, as the monomer solutions are less viscous than the diluted polymer resins, and will achieve deeper penetration under identical conditions [57]. An additional advantage of a monomer treatment is that, by combining different monomers, it would be possible to modify the properties of the resultant polymer to fit the condition of the stone [58].

Another recent impregnation technique using solvent-diluted polymer resins obtains penetration by first applying water-soluble solvent and water solutions, thereby removing water-soluble occlusions from the pores of the stone. The water is then displaced by gradually increasing the concentration of the solvent. In the final phase of treatment, resin, first diluted with solvent, then in concentrated form, is applied [59]. By saturating the stone with a solvent into which the resin can diffuse, a consequently deeper penetration is achieved than by application of a single resin-solvent system.

\section{Suggestions for the Evaluation of Stone Preservatives}

The following quoted eight points were proposed in 1921 as being the properties that an ideal stone preservative should fulfill [60]:

"1. It must penetrate easily and deeply into the stone, and remain there on drying.

2. It must not concentrate on the surface so as to form a hard crust, but at the same time harden the surface sufficiently to resist erosion.

*Defined in Appendix F. 
3. It must prevent penetration of moisture, and, at the same time, allow moisture to escape.

4. It must not discolor or in any way alter the natural appearance of the stone.

5. It must expand and contract uniformly with the stone so as not to cause flaking.

6. It must be non-corrosive and harnless in use.

7. It must be economical in material and labour of application.

8. It should retain its preservative effect indefinitely."

Such criteria are still valid; on the whole these are the properties that are wanted in a stone preservative. That any one material could fulfill them all is doubtful. When considering the varying types of stone, decay processes, structural designs, etc. that are factors in the performance of a preservative, it is understandable that in a 1963 report on Stone Preservatives the Building Research Establishment, Great Britain, reported that of the stone preservatives proposed since 1840, "no stone preservative used as a surface treatment has yet met with any significant measure of success" [61]. If general satisifaction cannot be achieved, perhaps the only qualification in matching a preservative to a stone is "does it work". Point 4 notes the importance of not altering the natural appearance of stone. The texture and fabric of natural stone, as well as its visual aspect from color and reflectance, should be retained in any preservation treatment. Changes in these qualities can thwart the entire purpose of historic preservation.

Points 7 and 8 of the above requirements merit comment. The cost of the stone preservative treatment and the practicality of its application to a structure are matters that the user must decide. The competence and experience of the workcrew doing the treatment must be known. Their willingness to comply with the supplier's recommended application procedure for his preservative is as vital to the performance of the preservative as is the quality.

Permanence of treatment should also be considered before application. Most stone preservative treatments are intended to be permanent. The question arises as to whether this permanence is wanted, if it would not preclude later use of better stone preservatives. The limited durability of some preservative treatments might, therefore, be advantageous. Periodic re-treatment has the additional benefit of necessitating reexamination of the condition of the stone before application of the preservative.

As the value of a preservative is only proven with time, the evaluation of any stone preservative treatment is how well it has done its job 
over a period of years. Unfortunately, retrospective answers are useless to the central question, before it is used, as to how good the preservative will be.

Evaluation of a preservative must, therefore, proceed through other methods. In general, these may be 1isted as: 1) the long term performance of the preservative as used on other stone structures; 2) testing the preservative on areas of the structure that it is intended to be used on; 3) and a laboratory test program of the preservative.

Stone structures that have been treated with preservatives are practical examples of the value of that preservative. Differences in climate or environment, type of stone, etc. between the treated and to-be-treated structure must be considered. One drawback to this approach is that with new stone preservatives there is a lack of information as to long term performance.

Before commitment to any preservative treatment, it is mandatory to set aside small, representative sections of the structure to test the compatibility of the preservative to the stone and to detect any short term effects on the stone, such as color changes, efflorescence, or other changes in appearance. The longer these preliminary tests can be carried out, the greater the opportunity to validate the effectiveness of the preservative and to detect any negative effects on the stone.

These first two evaluative methods may be combined by applying one or more preservatives to areas of old stone in structures that have undergone decay and to observe if there is any retardation of the decay between treated and untreated stone. (An example of such field trials is given in Appendix B.)

Laboratory test programs are one way of overcoming the lengthy time needed for the above methods of evaluation. Laboratory programs have the advantage that test conditions can be chosen to simulate the specific environment and climate that a preservative will be exposed to in use. (A list of various test methods that might be useful in a laboratory test program for stone preservatives is given in Appendix E.) In any case of stone preservation, there is a need to have knowledge of the materials, both of the stone that needs protection and of the preservative that affords that protection, and the ability to treat or to use them in a rational manner [62].

In conclusion, historic buildings and monuments are a heritage to be passed on to the future. Their care is a continuing problem; stone preservation cannot be a one-shot affair. In the words of one worker, "Ceaseless upkeep is, indeed, the only guarantee that a preservation treatment intended to arrest a spreading decay is transformed into a permanent safeguard" [63]. 
Both Mr. Arthur Hockman, Materials Research Engineer, and Dr. Geoffrey Frohnsdorff, Section Chief, of the Center for Building Technology, have given valuable advice and background information in the writing of this review. The assistance of the NBS library staff, who obtained the reference material used in this review, is gratefully acknowledged, as is the help of other members of NBS, too numerous to mention. 
The following series of test methods for building stone are taken from tests published by the American Society for Testing and Materials (ASTM) and the Deutsche Industrie Norms [German Industrial Standards] (DIN). In addition, a series of tentative recommended tests for natural and artificial stone developed by the RILEM* Technical Committee 6-PAN is given. One method of evaluating the effect of preservatives in preventing or retarding stone decay is to compare the results of tests run on treated and untreated stone specimens.

The test methods listed below are not meant to be all inclusive in regard to official tests on natural stone; their choice is based upon their availability at the time of writing.

DEUTSCHE INDUSTRIE NORMS (DIN)** [In German]

Series DIN 521 deals with Testing of Natural Stone.

DIN 52100 -- Guidelines for the Testing of Natural Stone.

DIN 52101 -- Sampling.

DIN 52102 -- Determination of Density, Bulk Density, True Density, Density Grade, True Porosity.

DIN 52103 -- Determination of Water Absorption.

DIN 52105 -- Compression Test.

DIN 52106 -- Principles for the Assessment of the Weathering Resistance.

DIN 52107 -- Resistance to Impact (Cubes).

DIN 52108 -- Wear Test with Grinding Wheel.

DIN 52111 -- Sodium Sulfate Crystallization Test.

DIN 52112 -- Flexure Test.

DIN 52113 -- Determination of Saturation Value.

*Reunions Internationales des Laboratoires d'Essais et de Recherches sur les Materiaux et les Constructions. [The International Union of Testing and Research Laboratories for Materials and Structures.] **

**Copies of individual DIN test methods may be obtained from BeuthVertrieb Gmbh, 1 Berlin 30, Burggrafenstrasse 4-7. 
C 97-47 -- Absorption and Bulk Specific Gravity of Natural Bu1lding Stone (Vol. 12).

C 99-52 -- Modulus of Rupture of Natural Bullding Stone (Vol. 12).

D 119-71. - Standard Definitions Relating to Natural Building Stones (Vol. 12).

C 170-50 -- Compressive Strength of Natural Building Stone (Vol. 12).

C 503-67 -- Standard Specification for Exterior Marble (Vol. 12).

C 241-51 -- Abrasion Resistance of Stone Subjected to Foot Traff1c (Vol. 12).

C 568-67 -- Standard Specification for Dimension Limestone (Vol. 12).

C 616-68 -- Standard Specification for Building Sandstone (Vo1. 12).

C 615-68 -- Standard Specification for Structural Granite (Vol. 12).

Testing Methods for Natural Stones, Recommended by RILEM Technical Committee 6-PAN (Materials \& Structures, Testing \& Research, 5, 231-260 $\underline{(1972)}$.

$1-\operatorname{SCOPE}$

2 - SAMPLING

3 - GRAVIMETRIC MEASUREMENTS

3.1 - General Testing Conditions

3.2 - Determination of the Bulk Density

3.3 - Determination of the Absolute Density

3.4 - Determination of the Porosity and Compactness

*ASTM Standards may be obtained by applying to the American Society for Testing and Materials, 1916 Race Street, Philadelphia, Pennsylvania 19103. 
4 - TESTS WITH REFERENCE TO WATER

4.1 - Definition

4.2 - Drying with Constant Mass

4.3 - Soaking by Initial, Progressive and Then Complete Immersal Up to Constant Mass

4.4 - Soaking in Water by Complete Immersal at Atmospheric Pressure

4.5 - Determination of Water Absorbed

4.6 - Soaking by Immersal-Ebullition

4.7 - Water Absorption with Lowered Air Pressure

4.8 - Water Absorption Under Pressure at 150 Bar

4.9 - Calculation of the Water Absorption Coefficient Under Lowered Air Pressure

4.10 - Calculation of the Saturation Coefficient

4.11 - Determination of the Water Content

4.12 - Water Absorption by Capillarity

5 - MECHANICAL TESTS ON SPECIMENS

5.1 - Characteristics of Specimens

5.2 - Preparation of Specimens

5.3 - Testing Methods 

The following is an example of how a laboratory program, by elucidating the cause of stone decay and by evaluating stone preservative treatments, can lead to the choice of the treatment appropriate to the problem.

In the 1950's, the stone temple of Somnath, India, located near the ocean, had a problem of serious stone decay. The first step of the scientists who were asked to investigate the problem was to determine what types of stone had been used in the building; each type was then analyzed, chemically and petrographically. Certain physical properties of the temple stone -- porosity, specific gravity, apparent density -were determined. After considering the location, the form of stone decay, and the properties of the stone, it was concluded that during the monsoon season salt water was blown inland from the ocean and was absorbed by the highly porous stone; when dry weather evaporated the absorbed water, the resultant crystallization of the salt shattered the stone. Prevention of stone decay would, in this instance, be based upon stopping the absorption of water by the stone -- in short, a water repellent was needed.

The effectiveness of various commercial materials were determined by a laboratory test program. Each water repellent was evaluated as to its capacity to reduce the water absorption and the porosity of specimens of the temple stone. The durability of each treatment and its resistance to color change were examined by a series of alternate wetting and drying cycles, using treated stone specimens.

A specific water repellent was recommended, based upon the results of the laboratory evaluation. Practical points were also noted in the report: the transitory nature of the water repellent, and the need for periodic re-treatment was stressed; a preliminary test of the water repellent upon a small area of the temple was advised; the health and fire hazards of the organic solvents used with the repellent treatment were explained. 



\section{APPENDIX D}

METHODS FOR CLEANING NATURAL BUILDING STONE

The major part of the following discussion of methods for cleaning natural building stone is a synopsis of that subject as presented in reference [66].

Water Spray -- Water spray is the cheapest, most easily applied method for cleaning stone. There is little possibility of damaging the stone, although open joints, etc. must be closed to prevent water penetration into the structure, with possible damage to interior surfaces. The slow soaking action of the water spray will loosen most surface deposits; some brushing action may be needed to remove the more adherent matter.

Steam Cleaning -- The advantages and working action of steam cleaning are approximate to those of the water spray treatment. The added expense of generating steam and the danger of steam to the cleaning personnel should be considered.

Dry Sandblasting -- Sandblasting is an abrasive process that scours deposits free from the stone surface. A serious drawback of any abrasive process is that it will remove decayed or soft stone as well as dirt.

Wet Sandblasting -- The effect on stone for wet sandblasting is the same as dry sandblasting, except that incorporating water in the sandblast tends to reduce the amount of dust that is raised.

Mechanical Cleaning -- Grinding operations use power tools with appropriate abrasive heads to remove surface deposits. It suffers from the same drawback as the sandblasting methods, i.e., removal of decayed and soft stone.

Chemical Cleaning -- The use of soaps, salt solutions, and diluted acids or bases for cleaning stone raises the possible danger of immediate chemical attack of the stone, or contamination of the stone by salts or residues that subsequently harm the stone. Hydrofluoric acid (and certain fluoride salts) will not attack unglazed building stones and will not leave soluble salts (it will attack glass and metal building materials).

Inconvenience to passersby should be considered before beginning any cleaning operation. Appropriate screening should be erected to block dust and/or water from cleaning procedures. Each cleaning method poses some potential hazard to the workcrew doing the cleaning. When dust or chemical fumes are evolved, suitable respirators, breathing apparatus and protective clothing will be needed. Chemical burns from hydrofluoric acid are especially pernicious. 
There should be adequate drainage to remove the liquid or solid wastes incident to the cleaning operation; the disposal of such wastes should conform to local ordinances. Other materials or areas of the structures being cleaned must be protected from the effects of the cleaning medium being used.

Lastly, any proprietary cleaning materials must be strictly guaranteed not to contain chemicals that will attack or leave deposits on the stone.

Stains on Stone -- Treatments for removing metallic residue stains from stone are given in a short discussion of cleaning stone in reference $[67]$. 
The most practical laboratory test program for stone preservatives is one that compares the results of tests run on specimens of treated and untreated stone. In such a program, the effectiveness of the preservative will be determined by how well it maintains the properties of the treated specimens relative to the untreated specimens.

There are three decisions that should be made prior to beginning any laboratory program in materials testing: first, what properties of the material are important for the study; second, what test methods will be useful for studying those properties; third, how can the tests results be evaluated relevant to the goal of the program.

Where specific problems of stone decay are of interest, laboratory testing should concentrate on those properties of the stone that are affected by this form of decay. When stone is exposed to exceptional environments or climates, these should be duplicated as nearly as possible in the laboratory. However, no laboratory test can simultaneously duplicate all the elements of an environment or climate.

In the example of stone preservation covered in Appendix D, duplication of the environment was not necessary as the cause of the stone decay (wind-carried salt) could be deduced from examination of the stone and knowledge of the environment. The effectiveness of the water repellents that were chosen for preserving the stone were evaluated by determining their capacity for reducing the water absorption of the stone; the durability of the preservative treatments was evaluated through a series of alternate wetting and drying cycles.

Where there is no specific stone structure involved, a broader test program can be set up. Standard test methods, such as those listed in Appendix A, can be used to measure those physical properties of the stone that are judged to be important. In addition, various climates or environments that are known to affect building materials have been standardized by ASTM and DIN. Some of these are included in the test methods listed below:

ASTM D 822 -- Recommended Practice for Operating Light- and Water-Exposure Apparatus (Carbon Arc Type) (Vo1. 21).

ASTM B 117-64 -- Standard Method of Salt Spray (Fog) Testing (Vol. 21). 
ASTM D 2247-68 -- Testing Coated Metal Specimens at 100 Percent Relative Humidity (Vol. 21)。

DIN 50017 -- Testing of Materials, Structural Components and Equipment, Method of Test in Damp Heat Alternating Atmosphere Containing Sulfur Dioxide*.

These and similar test methods developed for materials other than stone can often be used for measuring properties of stone. Some additional ASTM methods that may prove useful are:

ASTM D 2244-68 - Instrumental Evaluation of Color Differences of Opaque Materials (Vol. 21).

ASTM D 523-67 -- Standard Method of Test for Specular Gloss (Vo1. 21).

ASTM E 18-67 -- Standard Method for Rockwell Hardness and Rockwell Superficial Hardness of Metallic Materials (Vo1. 31).

ASTM C 215-60 -- Standard Method for Fundamental Transverse, Longitudinal, and Torsional Frequencies of Concrete Specimens (Vol, 10).

ASTM C 355-64 -- Standard Methods for Water Vapor Transmission of Thick Materials (Vol. 14).

ASTM C 341-54T -- Tentative Test Method for Volume Changes of Concrete Products (Vo1, 10).

ASTM C 295-65 -- Recommended Practice for Petrographic Examination of Aggregates for Concrete (Vo1. 10).

ASTM C 92-46 -- Standard Method for Sieve Analysis and Water Content of Refractory Materials (Vo1. 13).

In addition to the test methods that have been standardized for investigating the properties of stone, there is special instrumentation and methodology that is of value for examining and analyzing the surface manifestations of stone decay. Some of these useful for examining surface effects are:

Microscopy -- A microscope is essential for a thorough study of stone. High magnification is not necessary for general observations,

*Further information about the advantages of this test can be found in reference [68]. 
and is not possible with large stone specimens. Higher magnifications (up to 1000 diameters enlargement) and an extended capability in microscopic technique and equipment would be needed for more sophisticated analysis of the stone (for example, in petrographic studies). Whatever the microscope, some photographic attachment is needed for obtaining photomicrographs as permanent records of the condition of the stone specimens.

Scanning Electron Microscope (SEM), Electron- and Ion-Microprobe -These instruments make it possible to observe or analyze micrometer areas of a specimen. The scanning electron microscope can give useful magnifications from 20 to 20,000 diameters, with great depth of field. Photographic capabilities are standard and, with some instruments, qualitative $\mathrm{X}$-ray emission data can be obtained from the region being examined. Electron- and Ion-microprobe instruments can give a quantitative chemical analysis for surface areas only a few microns in diameter. With most of these instruments, specimen size is restricted. The specimens' surfaces must be electrically conductive, consequently, stone specimens have to be coated with a thin layer of conductive material.

Powder X-ray Diffraction -- With the usual commercial X-ray instruments, several milligrams of material will be needed for obtaining Xray diffraction patterns. However, it is an excellent method for characterizing crystalline products that may be formed on the surface of stone during decay. For example, through X-ray diffraction it is possible to differentiate calcium sulfite from calcium sulfate salts, a difference difficult to detect by wet chemical analysis.

Thermal Mechanical Analysis (TMA) - - Instruments of this type permit continuous thermal expansion measurements to be made over wide temperature ranges. Such information may be of value in detecting what stones may deform under thermal stress, and the effect preservatives may have in preventing or modifying this change. 


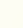




\section{APPENDIX F}

\section{GLOSSARY OF TECHNICAL TERMS}

Efflorescence -- A visible deposit of soluble salts, often white in color, that has been carried by water to the surface of masonry.

Granite (scientific definition) -- A visibly granular, crystalline rock of predominately interlocking texture, composed essentially of alkalic feldspars and quartz; this is a true granite.*

Limestone -- A rock of sedimentary origin composed principally of calcium carbonate (the mineral calcite), or the double carbonate of calcium and magnesium (the mineral dolomite).*

Marble (scientific definition) -- A metamorphic (recrystallized) limestone composed predominately of crystalline grains of calcite or dolomite, or both, having interlocking or mosaic texture.*

Monomer -- A relatively simple compound which can react to form a polymer.**

Polymer -- A high molecular weight organic compound, natural or synthetic, whose structure can usually be represented by a repeated small unit, the mer; e.g. polyethylene, rubber, cellulose. Synthetic polymers are formed by polymerization of monomers.**

Sandstone -- A consolidated sand in which the grains are composed chiefly of quartz or quartz and feldspar, and with various interstitial bonding materials, including silica, iron oxides, calcite, or clay.*

Silicone -- One of the family of polymeric materials in which the recurring chemical group contains silicon and oxygen atom as links in the main chain. The various forms obtainable are characterized by their resistance to heat and low coefficients of thermal expansion.**

Resin -- Any of a class of solid or semi-solid organic products of natural or synthetic origin, generally of high molecular weight, with no definite melting point. Most resins are polymers.**

Vent -- A naturally occurring fissure, or line of weakness, in the stone.

\footnotetext{
*"Standard Definitions of Terms Relating to Natural Building Stones," ASTM C 119-71, Philadelphia: American Society for Testing Materials (ASTM), 1971.
}

**"Plastics Glossary," Modern Plastics Encyclopedia. New York: McGrawHill, Inc., 1969-1970. pp. 37-52F. 



\section{G.I Source Materials on Stone Preservation}

The textbooks or lengthy reports that concentrated on stone, its condition, deterioration, and preservation have been published mainly in the past; most books of this type that were used in writing this review were published prior to 1932. To assist those interested in stone preservation, they will be briefly described.

The book by Kieslinger ("Deterioration of Stone Buildings, Its Causes and Its Prevention", reference [16]) gives a thorough, extensive treatment of the causes of stone decay, the types of stone used in Austrian construction, and the methology of stone protection. Although the post-1932 materials used for stone preservation are not included, the discussion of stone decay remains valid. The pictorial examples of stone decay (there are 291 illustrations in the book) are excellent. The text is in German.

Still available is the report of Schaffer ("The Weathering of Natural Building Stone", reference [9]). This report was reprinted in 1949, and reissued in facsimile form in 1972, with addition of an appendix on the cleaning of stone (reference [66]). (Information as how to obtain this publication may be had by writing the Publications Officer, Building Research Establishment, Garston, Watford WD2 7JR, Great Britain.) A shorter publication (149 pp.) than Kieslinger's book, this report covers its subject in a simple, straightforward manner. Pictures illustrate the points discussed in the text, and there is an extensive bibliography relating to publications prior to 1932 .

Also available from the British Research Establishment is the 1967 publication "The Changing Appearance of Buildings" by R. B. White, ARIBA. This review illustrates the change in appearance of exterior building materials in the London area. Natural and cast stone, brickwork, terracotta, concrete and renderings, timbers and aluminum alloys are the building materials pictured. Examples of the deterioration of these materials -- often through improper usage or poor building design -or their sometimes fortuitous alteration of appearance, are given in 62 photographs.

The value of the book by Shore ("The Stone of Britain", reference [27]) is summed up by its subtitle, "A Pictorial Guide to Those in Charge of Valuable Buildings". Coverage, with numerous photographs, is limited to Britain. The author has definite opinions about building stones, and Britain, that are stated with conviction. 
The book by Warnes ("Building Stones, Their Properties, Decay, and Preservation", reference $[10]$ ) also covers the subject thoroughly. Warnes is not remiss in criticizing certain techniques for stone preservation; his critique of the materials and techniques used before 1926 is both valuable and relevant to their use today.

The recent book by Winkler ('Stone: Properties, Durability in Man's Environment" [69]) is more scientifically-oriented than those mentioned above: it attempts to supply a solid basis for making practical judgements in problems of stone decay. There are numerous graphs and illustrations throughout the book and a thorough bibliography.

The annotated bibliography of Lewin ("The Preservation of Natural Stone, 1839-1965", reference [32]) is a most valuable resume of the field of stone preservation prior to 1965. Of especial interest is the synopsis of the more important references.

The conference reports and publications of various international organizations engaged in preservation have, in part, supplanted the textbooks in this field. The latest techniques and materials, and examples of the preservation of historical structures, both of stone and other materials, are covered in the reports of these conferences. The proceedings of the 1971 Bologna meeting on the "Treatment of Stone" (ICOM, ICOMOS) may be bought from The International Centre for Conservation, Via San Michele 13; 00153, Rome, Italy. The proceedings of the 1970 New York Conference on "Preservation and Conservation of Stone and Wooden Objects", (IIC), may be purchased from The International Institute for Conservation of Historic and Artistic Works, 608 Grand Buildings, Trafalgar Square, London, WC2N 5HN, Great Britain.

The minutes of the "First International Symposium on the Deterioration of Building Stones," held in September 1972 in La Rochelle, France, have recently been published. Excellent photographs accompany the 36 scientific reports on stone decay and stone preservation in this 237 page publication. All reports are in English or French with an abstract in the other language; the majority are in French. These minutes are available from: C.R.E.0., 73-77, rue de Sevres, 92100 Boulogne, France, at a cost of 350 Francs plus 7 Francs postage.

The National Building Research Institute of South Africa has compiled a "Handbook of South African Natural Building Stone," which covers the subject of natural building stone from quarrying to restoration; there is only one chapter concerned solely with South African building stone. of particular interest to architects should be the chapters on application of stone to present day building, and the choice of materials to be used in conjunction with stone. Information concerning this handbook may be obtained from the National Building Research Institute, CSIR, PO Box 395, Pretoria, South Africa. 
In listing these books and publications, the intent has been to supply some basic sources of information about stone preservation to new workers in the field, and not to try to give an all-inclusive summary of what is worthwhile in the literature pertaining to stone preservation.

\section{G.2 Bibliography}

[1] Public Law 89-665, 89th Congress, S.3034, October 15, 1966.

[2] "Weekly Compilation of Presidential Documents", Vol. 7, number 7 , pages 183-224, February 15, 1971.

[3] "Historic Buildings", Britannica Book of the Year, 1969, (Chicago, 1970), 385 .

[4] Marsh, James E., Stone Decay and Its Prevention. Oxford: Basil Blackwel1, 1926 .

[5] Schaffer, R. J., The Weathering of Natural Building Stone. Special Report number 18 of the Department of Scientific and Industrial Research. London: His Majesty's Stationery Office, 1932. pp. 1213.

[6] Schaffer, R. J. ibid. p. 13.

[7] Riederer, Josef. "Stone Preservation in Germany", New York Conference on Conservation of Stone and Wooden Objects, 7-13 June, 1970. London: International Institute for Conservation of Historic and Artistic Works. p. 126.

[8] Schaffer, R. J. op. cit. P. 12 .

[9] Schaffer, R. J. op. cit. p. 23.

[10] Warnes, Arthur R. Building Stones, Their Properties, Decay, and Preservation. London: Ernest Benn Ltd., 1926. pp 149-150.

[11] Kessler, Danie1 W. and Ross E. Anderson, "Influence of the Wash from Bronze on the Weathering of Marble", Building Materials and Structures Report 137. Washington: U. S. Government Printing Office, 1953.

[12] "Freeze Damages Some Roman Ruins", The Washington Post, February 14, 1963.

[13] Hockman, Arthur and Danie1 W. Kessler, "Thermal and Moisture Expansion Studies of Some Domestic Granites", Journal of Research of the National Bureau of Standards, 44, 395 (1950). 
[14] Torraca, Giorgio. "Masonry and Masonry Materials - Brick, Adobe, Stone and Architectural Ceramics -- Deterioration Processes and Conservation Practices", North American International Regional Conference, Williamsburg and Philadelphia, Sept. 10-16, 1972. p. 7.

[15] Riederer, Josef. op. cit., p. 129.

[16] Kieslinger, Alois, Zerstoerungen an Steinbauten, Ihre Ursachen and Ihre Abwehr. Leipzig u. Wien: Franz Deuticke, 1932. p. 136.

[17] Warnes, Arthur R. op. cit., pp. 133-134.

[18] Winkler, Erhard M. "Important Agents of Weathering for Building and Monumental Stone", in Engineering Geology 1, p. 381 (1966).

[19] Riederer, Josef. op. cit., p. 127.

[20] Schaffer, R. J., op. cit., p. 25.

[21] Greathouse, Glenn A., Bryston Fleer, and Carl J. Wesse1, "Chemical and Physical Agents of Deterioration", Deterioration of Materials, Causes Preventive Techniques, ed. Glenn A. Greathouse and Carl J. Wesse1, New York: Reinhold Publishing Corp., 1954. p. 106.

[22] Winkler, Erhard M., op. cit., p. 383.

[23] Greathouse, Glenn A., op. cit., p. 105.

[24] Schaffer, R. J., 으. cit., pp. 25-26.

[25] Riederer, Josef, 으. cit., pp. 126-128.

[26] Warnes, Arthur R., op. cit., p. 211.

[27] Shore, B.C.G., Stones of Britain. London: Leonard Hill (Books) Ltd., 1957. pp. 30-31.

[28] Schaffer, R. J., op. cit., p. 76.

[29] Schaffer, R. J., op. cit., pp. 73-75.

[30] Schaffer, R. J., op. cit., pp. 77-81.

[31] Kauffman, Jacques, Corrosion-Anticorrosion, 8 , 87-95 (1960).

[32] Lewin, Seymour Z. "The Preservation of Natural Stone, 1839-1965, An Annotated Bibliography", Art and Archaeology Technical Abstracts, 6, 185-277, 188-189 (1966).

[33] Shore, B.C.G., op. cit., pp. 164-181. 
[34] Schaffer, R. J., op. cit., pp. 29-30.

[35] Sofianopoulos, A. J., Journal of Chemical Education, 28, 79 (1951).

[36] Schaffer, R. J., Journal of the Royal Society of Arts, 103, 851 (1955).

[37] Warnes, Arthur R., op. cit., pp. 251-252.

[38] Burgess, S.G., and R. J. Schaffer, Chemistry and Industry, 1026-1029 (1952).

[39] Hedval1, J. A. Ber. Dtsch. Keram. Ges., 39, 37 (1962).

[40] Warnes, Arthur R., op. cit., p. 242.

[41] Wihr, Rolf, and Gerhard Steenken, "On the Preservation of Monuments and Works of Art with Silicates", in New York Conference on Conservation of Stone and Wooden Objects, 7-13 June, 1970. London: International Institute for Conservation of Historic and Artistic Works. pp. 71-75.

[42] Warnes, Arthur R., op. cit., p. 244.

[43] Stambolov, Todor, "Conservation of Stone", in New York Conference on Conservation of Stone and Wooden Objects, 7-13 June, 1970. London: International Institute for Conservation of Historic and Artistic Works. p. 119.

[44] Linke, William. Solubilities of Inorganic and Metal-Organic Compounds, Vol. I Princeton, NJ: D. Van Nostrand, 1958. p. 630.

[45] Church, A. A., British Patent 200, Jan. 28, 1862, as reported in Lewin, Seymour Z., op. cit., p. 193.

[46] Walton, Harold F., Principles and Methods of Chemical Analysis, 2nd Ed. Englewood Cliffs, NJ: Prentice Hall, Inc., 1964, pp 55-67.

[47] Lewin, Seymour Z., "The Conservation of Limestone Objects and Structures" in Study of Weathering of Stone, Vo1. 1. Paris: International Council of Monuments and Sites, 1968.

[48] Sayre, Edward V., "Direct Deposition of Barium Sulfate from Homogeneous Solution Within Porous Stone", in New York Conference on Conservation of Stone and Wooden Objects, 7-13 June 1970. London: International Institute for Conservation of Historic and Artistic Works, pp. 115-118.

[49] Marsh, James E., op. cit., p. 49.

[50] Hedvall, J. A., op. cit., p. 37. 
[51] Stambolov, Todor, op. cit., p. 120.

[52] Stambolov, Todor, op. cit., p. 119.

[53] Munnikendam, R. A. Studies in Conservation, 12, 158 (1967).

[54] Munnikendam, R. A., ibid, p. 158.

[55] Munnikendam, R. A., ibid, p. 158.

[56] Munnikendam, R. A., "Acrylic Monomer Systems for Stone Impregnation", in New York Conference on Conservation of Stone and Wooden Objects, 7-13 June, 1970. London: International Institute for Conservation of Historic and Artistic Works, pp. 15-18.

[57] Munnikendam, R. A., op. cit., p. 158.

[58] Munnikendam, R. A., op. cit., p. 17.

[59] Gauri, K. L., Nature, 228, 882 (1970).

[60] Warnes, Arthur R., op. cit., p. 227.

[61] Building Research Station Digest -- First Series, Number 128, Nov. 1959 -- Revised June 1963. London: Her Majesty's Stationery Office, 1963.

[62] Stambolov, Todor, o․ it., p. 119-120.

[63] Stambolov, Todor, op. cit., p. 121.

[64] Clarke, B. L., and J. Ashurst, "Stone Preservation Experiments"

(Building Research Establishment) Building Research Station, Garston, Watford WD2 7JR. 1972.

[65] Roy, B. B., as quoted in J. A. Hedval1, Chemie im Dienst der Archaeologie Bautechnik Denkmalpflege Goeteborg: AkademifoerlagetGumperts, 1962. 204-209.

[66] Building Research Establishment (Great Britain). Cleaning External Surfaces of Buildings. Building Research Station, Garston, Watford WD2 7JR. 1973.

[67] Stambolov, Todor, op. cit., pp. 120-121.

[68] Kesternich, W. Werkstoffe u. Korrosion, 13, 193 (1965).

[69] E. M. Winkler, Sonte: Stone: Properties, Durability in Man's Environment, Springer Verlag, New York, 1973. 
NUS., I4A IREV.7-73)

\begin{tabular}{|c|c|c|c|}
\hline $\begin{array}{l}\text { U.S. DEPT. OF COMM. } \\
\text { BIBLIOGRAPHIC DATA } \\
\text { SHEET }\end{array}$ & $\begin{array}{l}\text { 1. PUBLLICATION OR RI:PORT NO. } \\
\text { NBSIR } 74-444\end{array}$ & $\begin{array}{l}\text { 2. Gov't Accession } \\
\text { No. }\end{array}$ & 3. Recipient's Accession No. \\
\hline \multirow{2}{*}{\multicolumn{3}{|c|}{ A Review, of Natural Stone Preservation }} & $\begin{array}{l}\text { 5. Publication Date } \\
\text { December } 1973\end{array}$ \\
\hline & & & 6. Performing Organization Code \\
\hline \multirow{3}{*}{\multicolumn{3}{|c|}{$\begin{array}{l}\text { 7. AUTHOR(S) } \\
\text { Gerald Sleater } \\
\text { 9. PERFORMING ORGANIZATION NAME AND ADDRESS } \\
\text { NATIONAL BUREAU OF STANDARDS } \\
\text { DEPARTMENT OF COMMERCE } \\
\text { WASHINGTON, D.C. } 20234\end{array}$}} & $\begin{array}{l}\text { 8. Performing Organ. Report No. } \\
\text { NBSIR } 74-444\end{array}$ \\
\hline & & & 10. Project/Task/Work Unit No. \\
\hline & & & 11. Contract/Grant No. \\
\hline \multirow{2}{*}{\multicolumn{3}{|c|}{ 12. Sponsoring Organization Name and Complete Address (Street, City, }} & $\begin{array}{l}\text { 13. Type of Report \& Period } \\
\text { Covered } \\
\text { Interim }\end{array}$ \\
\hline & & & 14. Sponsoring Agency Codc \\
\hline \multicolumn{4}{|l|}{ 15. SUPPIEMENTARY NOTES } \\
\hline \multicolumn{4}{|c|}{$\begin{array}{l}\text { 16. ABSTRACT (A 200-word or less factual summary of most significant information. If document includes a significant } \\
\text { bibliography or literature survey, mention it here.) }\end{array}$} \\
\hline \multicolumn{4}{|c|}{$\begin{array}{l}\text { With increased interest in stone preservation, it is desirable to know what } \\
\text { causes stone to decay, and what materials can be used to preserve stone. This } \\
\text { review covers the following topics: causes of stone decay, including faults } \\
\text { in the stone, salts, natural weathering factors, air pollution, living organisms, } \\
\text { and most importantly, water action; various materials that have been used to } \\
\text { preserve stone, including paints, waxes, oils, inorganic chemical surface } \\
\text { treatments and impregnants, silicones, siliconates, and synthetic organic polymers; } \\
\text { methods of evaluating stone preservatives. Field and laboratory procedures } \\
\text { for testing stone preservatives, the cleaning of stone, a glossary, and a } \\
\text { bibliography are given in appendices. }\end{array}$} \\
\hline
\end{tabular}

17. KEY WORDS (six to twelve entries; alphabetical order; capitalize only the first letter of the first key word unless a proper name; separated by semicolons)

Air pollution; historic structures; laboratory evaluation; natural weathering; stone decay; stone preservation.
18. AVAILABILITY
Ex Unlimited

For Official Distribution. Do Not Release to NTIS

Order From Sup. of Doc., U.S. Government Printing Office

Washington, D.C. 20402, SD Cat. No.C.I3

X Order I rom National Technical Information Service (NTIS) Springfield, Virginia 22I51

\begin{tabular}{|l|c|}
\hline $\begin{array}{l}\text { 19. SECURITY CLASS } \\
\text { (THIS REPURT) }\end{array}$ & 21. NO. OF PAGES \\
UNCLASSIFIED & 39 \\
\hline $\begin{array}{l}\text { 20. SECURITY CLASS } \\
\text { (THIS PAGE) }\end{array}$ & 22. Price \\
UNCLASSIFIED & \\
\hline
\end{tabular}





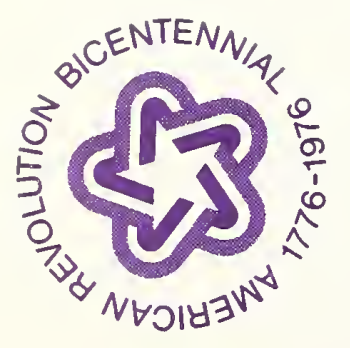

